\title{
Spectrum of Bacterial Isolates from Captive Non-Human Primates in Jos Wild Life Park
}

\author{
${ }^{* 1}$ Okwori, A.E.J , ${ }^{1}$ Ofili A. I., ${ }^{1}$ Uzoechina. A.R., ${ }^{2}$ Nwankiti., O., ${ }^{2}$ Chollom, S.C., \\ ${ }^{1}$ Echeonwu, G.O.N., ${ }^{3}$ Adikwu T.I \\ ${ }^{1}$ Department of Medical Microbiology, Federal College of Veterinary and Medical \\ Laboratory Technology, ${ }^{2}$ National Veterinary Research Institute, Vom - Jos, ${ }^{3}$ Royal Infirmary Hospital, \\ Edinburgh, UK.
}

\begin{abstract}
Primates refer to a zoological order of placental mammals, consisting of lemurs, bushbabies, tarsiers, marmosets, monkeys, apes, and humans. In an effort to evaluate the occurrence of bacterial organisms with zoonotic and biohazard potential in captive non-human primates (NHP) in the park, we performed a prevalence study examining 18 aparently healthy young adult monkeys and apes. We sampled them by faecal culture on three separate occasions using appropriate media and specific selective culture methods. The survey lasted for a period of three months with sampling at 2 weeks intervals. Enteric organisms potentially transmissible to humans were subcultured and identified based on their morphological and biochemical characteristics. Prevalence results at start and finish points obtained revealed six (6) bacterial organisms as follows: Escherichia coli (100.0\%), Salmonella paratyphi A (72.8.0-77.8\%), Proteus mirabilis (61.1-83.3\%), Campylobacter species (5.6\%), Citrobacter ferundii 13(16.7-33.3\%), and Yersinia enterocolitica (22.4\%). The presence of these pathogenic bacteria has public health significance because of the nature and use of their location (being a park) and its proximity to human dwellings. We recommend proper hygienic husbandry and vigilant sampling of NHP populations anywhere they are kept; also the appropriate use of antibiotics to eliminate shedding of bacteria and spread of the disease should be undertaken.
\end{abstract}

Key Words: Non-human primates, zoonotic bacteria, Jos- Nigeria.

\section{Introduction}

A host of bacteria are commonly seen in apparently healthy non-human primates (NHPs). Some include Mycobacterium tuberculosis, Shigella spp, Salmonella spp, Escherichia coli, Campylobacter spp and Klebseilla spp (Nizeyi et al., 2001); Helicobacter spp has also been recently reported in monkeys (Bronsdon and Schoenknecht, 1988; Fox et al., 2001).

Some of these pathogens endemic in NHP populations remain clinically inapparent in immunocompetent animals and are in general mild and self limiting; as such they do not adversely affect their lives. The exceptions are those infections associated with the gastrointestinal tract that result in chronic enterocolitis, a condition that, albeit of low incidence, is a persistent and wide spread colony problem in NHPs and is most likely multifactorial in origin (Sestak et al., 2003). In addition, immunosuppression, introduced either naturally (e.g., by immunosuppressive retroviruses) or experimentally (e.g., by irradiation, immunomodulatory agents, or chemotherapeutics), can make a previously unexposed animal or group more susceptible to primary outbreaks or induce recrudescence of these pathogens. Bacterial infections commonly associated with immunosuppression include Mycobacterium avium complex, Rhodococcus equi, and enteropathogenic Escherechia coli (EPEC) (Mansfield et al., 2001).

Almost all primates harbour E. coli, Shigella spp and Salmonella spp in the alimentary tract. Fortunately the most serious human pathogens of these two groups Shigella dysenterriae type I and Salmonella typhi, (Srivastava et al., 1980) have only rarely been isolated from NHPs. However, several other species including Shigella flexneri, S. Sonnii, Salmonella typhimirium and S. indiana which are also infectious to man, have been recovered from monkeys (Basu et al., 1975; Boro et al., 1980).

The primate carrying any of these organisms can have a fulminating fatal infection at anytime, with excretion of large numbers of organisms during the course of the disease or as silent shedders, which can then be transmitted to humans (Mohan et al., 1973). The presence of these pathogenic bacteria has public health significance because of proximity of NHPs to human dwellings (Mohan et al., 1973) and cross species transmission of infection (Lerche et al., 2001; Engel et al., 2002; Wolfe et al., 2004; Engel et al., 2002., 2006) though this is dependent on several factors: the prevalence of infectious agents in primate reservoirs, the context of interspecies contact and the frequency with which contact occurs (Engel et al., 2006). By virtue of their genetic, physiologic and behavioural similarity to humans, NHPs are particularly likely sources of emerging infectious agents with the capacity to infect humans, and primate-to-human cross-species transmission of infectious agents has become a focus of scientific enquiry. Moreover, despite significant advances in the 
diagnosis of infectious diseases, unrecognized or adventitious agents are common in NHPs and have the potential to confound experimental work (Barley and Mansfield, 2010).

Recent studies in India and Africa have revealed a large presence of enteric pathogens from non-human primates including major pathogens like Salmonella spp, Shigella spp and Campylobacter jejuni. These reports has necessitated the need for us to examine such animals in close contact with humans in our environment for the presence of these zoonotic pathogens.

\section{STUDY AREA}

\section{Methodology}

This study was conducted at Jos zoo situated in Jos metropolis, Plateau State, Nigeria for the determination of enteric bacterial microflora in apparently healthy, captive non-human primates.

\section{STUDY POPULATION: NON-HUMAN PRIMATES (NHPs)}

The study population cut across 18 non-human primates (monkeys and apes) held in captivity. The majority of animals studied in the 90 days period were initially received by the zoo as donations from private individuals. Most other primates were obtained from the wild from various parts of the country. The species present were: Cercopithecus mona (1), Chlorocebus tantalus (1), Erythrocebus patas (5), Papio Anubis (8) and Pantroglodytes (3).

\section{SAMPLES, SAMPLING AND PROCESSING}

Samples were fresh excreta from the animals. They were taken in duplicates by deeply inserting and rotating a sterile cotton swab $15 \mathrm{~cm}$ long into freshly passed faeces. They were then transported with minimal delay to the laboratory. Samples were analyzed at the Bacteriology laboratory of Federal College of Veterinary and Medical Laboratory Technology, N.V.R.I, Vom.

\section{BACTERIOLOGICAL PROCEDURES}

The procedures for the culture and isolation of Campylobacter species were similar to the methods of Bolton et al. (1988), while those for Yersinia species and other enteric bacteria were a modification of the methods of FDA/CFSAN (2001) and Okwori et al (2005) respectively.

Swabs were used to directly inoculate Improved Preston blood-free Agar plates and MacConkey Agar (MCA) plates, and were then placed in Selenite F broth. After 24 hours of incubation, Selenite F broth cultures were streaked onto Deoxycholate Citrate Agar (DCA) plates.

About 1 gram of faecal sample was aseptically inoculated into $10 \mathrm{ml}$ of phosphate buffered saline (PBS) $\mathrm{pH}$ 7.2, homogenized for about 30 seconds and incubated at $4^{\circ} \mathrm{C}$ for 21 days (FDA/CFSAN, 2001). The inoculated PBS was subcultured onto solid culture plates of BA and MCA, and incubated at room temperature $\left(24^{\circ} \mathrm{C}\right)$ for 24 and 48 hours respectively.

Plates of Improved Preston blood-free medium were examined for Campylobacter organisms after 48 hours microaerophilic incubation at $37^{\circ} \mathrm{C}$; grey, moist, flat-spreading colonies; creamy-grey, moist slightly raised greenish colonies were selected. Preferences were given to isolates that gave the following results:

(i) Gram reaction - Negative 'S' shaped bacilli

(ii) Oxidase - Positive

(iii) Catalase - Positive

(iii) Motility - Positive (actively darting)

Culture plates of BA and MCA incubated at $24^{\circ} \mathrm{C}$ for 24 and 48 hours respectively were examined for Yersinia species. On BA, smooth, translucent, non-haemolytic colonies measuring 2-3 mm in diameter were selected. On MCA pinpointed non-lactose fermenting colonies were selected. The selected colonies were further inoculated into Christensen's urea agar by stabbing with a straight wire and incubated at room temperature for 18 hours.

Plates of MCA and DCA incubated at $37^{\circ} \mathrm{C}$ were purified and examined for enterobacteriaceae. Pure isolates were inoculated into TSIA slants and peptone water broth and further examined for hydrolysis of urea, utilization of citrate and indole production, motility and deamination of phenylalanine. All results obtained were compared against a standard biochemical chart for Enterobacteriaceae.

\section{Results}

All $18(100 \%)$ of the NHP sampled were positive for suspected bacterial infection. This figure remained constant throughout the entire survey period. We isolated the following bacteria with the prevalences at the start and end of our investigations as follows: Escherichia coli (100.0\%), Salmonella paratyphi A (72.8.0- 77.8\%), Proteus mirabilis (61.1-83.3\%), Campylobacter species (5.6\%), Citrobacter ferundii 13(16.7-33.3\%), and 
Yersinia species (22.4\%) through out the course of our investigations. Details are as presented in tables 1 to 3.

Table 1: Isolates from sampled NHPs on the first sampling (first week)

\begin{tabular}{|l|l|l|l|l|l|l|l|}
\hline Primate species & $\begin{array}{l}\text { Nos of } \\
\text { primates } \\
\text { screened }\end{array}$ & $\begin{array}{l}\text { Escherichia } \\
\text { coli }\end{array}$ & $\begin{array}{l}\text { Salmonella } \\
\text { paratyphi }\end{array}$ & $\begin{array}{l}\text { Proteus } \\
\text { mirabilis }\end{array}$ & $\begin{array}{l}\text { Campylobacter } \\
\text { species }\end{array}$ & $\begin{array}{l}\text { Citrobacter } \\
\text { ferundii }\end{array}$ & $\begin{array}{l}\text { Yersinia } \\
\text { enterocolitica }\end{array}$ \\
\hline $\begin{array}{l}\text { Cercopithecus } \\
\text { mona }\end{array}$ & 1 & $1(100.0)$ & $1(100.0)$ & $1(100.0)$ & $0(00.0)$ & $1(100.0)$ \\
\hline $\begin{array}{l}\text { Chlorocebus } \\
\text { tantalus }\end{array}$ & 1 & $1(100.0)$ & $1(100.0)$ & $1(100.0)$ & $0(00.0)$ & $0(00.0)$ \\
\hline $\begin{array}{l}\text { Erythrocebus } \\
\text { patas }\end{array}$ & 5 & $5(100.0)$ & $4(80.00)$ & $5(100.0)$ & $1(20.00)$ & $0(00.0)$ \\
\hline Papio Anubis & 8 & $8(100.0)$ & $6(75.0)$ & $1(12.5)$ & $0(00.0)$ & $3(20.0)$ \\
\hline Pantroglodytes & 3 & $3(100.0)$ & $1(33.2)$ & $3(100.0)$ & $0(00.0)$ & $0(00.0)$ & $0(00.0)$ \\
\hline Total & $\mathbf{1 8}$ & $\mathbf{1 8}(\mathbf{1 0 0 . 0})$ & $\mathbf{1 3 ( 7 2 . 2 )}$ & $\mathbf{1 1}(\mathbf{6 1 . 1})$ & $\mathbf{1 ( 5 . 6 )}$ & $1(33.3)$ \\
\hline
\end{tabular}

Table 2: Isolates from sampled NHPs on the second sampling (sixth week)

\begin{tabular}{|l|l|l|l|l|l|l|l|}
\hline $\begin{array}{l}\text { Primate } \\
\text { species }\end{array}$ & $\begin{array}{l}\text { Nos of } \\
\text { primates } \\
\text { screened }\end{array}$ & $\begin{array}{l}\text { Escherichia } \\
\text { coli }\end{array}$ & $\begin{array}{l}\text { Salmonella } \\
\text { paratyphi }\end{array}$ & $\begin{array}{l}\text { Proteus } \\
\text { mirabilis }\end{array}$ & $\begin{array}{l}\text { Campylobacter } \\
\text { species }\end{array}$ & $\begin{array}{l}\text { Citrobacter } \\
\text { ferundii }\end{array}$ & $\begin{array}{l}\text { Yersinia } \\
\text { enterocolitica }\end{array}$ \\
\hline $\begin{array}{l}\text { Cercopithecus } \\
\text { mona }\end{array}$ & 1 & $1(100.0)$ & $1(100.0)$ & $1(100.0)$ & $0(00.0)$ & $1(100.0)$ \\
\hline $\begin{array}{l}\text { Chlorocebus } \\
\text { tantalus }\end{array}$ & 1 & $1(100.0)$ & $1(100.0)$ & $1(100.0)$ & $0(00.0)$ & $0(00.0)$ \\
\hline $\begin{array}{l}\text { Erythrocebus } \\
\text { patas }\end{array}$ & 5 & $5(100.0)$ & $4(80.00)$ & $5(100.0)$ & $1(20.00)$ & $0(00.0)$ \\
\hline Papio Anubis & 8 & $8(100.0)$ & $6(75.0)$ & $5(62.5)$ & $0(00.0)$ & $1(20.0)$ & $3(60.0)$ \\
\hline Pantroglodytes & 3 & $3(100.0)$ & $2(66.7)$ & $3(100.0)$ & $0(00.0)$ & $0(00.0)$ & $1(33.3)$ \\
\hline Total & $\mathbf{1 8}$ & $\mathbf{1 8}(\mathbf{1 0 0 . 0}$ & $\mathbf{1 4}(\mathbf{7 7 . 8})$ & $\mathbf{1 5}(\mathbf{8 3 . 3})$ & $\mathbf{1 ( 5 . 6 )}$ & $\mathbf{3}(\mathbf{1 6 . 7})$ & $\mathbf{4}(\mathbf{2 2 . 4})$ \\
\hline
\end{tabular}

Table 3: Isolates from sampled NHPs on the third sampling (twelft week)

\begin{tabular}{|l|l|l|l|l|l|l|l|}
\hline \multirow{2}{*}{$\begin{array}{l}\text { Primate } \\
\text { species }\end{array}$} & $\begin{array}{l}\text { Nos of } \\
\text { primates } \\
\text { screened }\end{array}$ & $\begin{array}{l}\text { Escherichia } \\
\text { coli }\end{array}$ & $\begin{array}{l}\text { Salmonella } \\
\text { paratyphi }\end{array}$ & $\begin{array}{l}\text { Proteus } \\
\text { mirabilis }\end{array}$ & $\begin{array}{l}\text { Campylobacter } \\
\text { species }\end{array}$ & $\begin{array}{l}\text { Citrobacter } \\
\text { ferundii }\end{array}$ & $\begin{array}{l}\text { Yersinia } \\
\text { enterocolitica }\end{array}$ \\
\hline $\begin{array}{l}\text { Cercopithecus } \\
\text { mona }\end{array}$ & 1 & $1(100.0)$ & $1(100.0)$ & $1(100.0)$ & $0(00.0)$ & $1(100.0)$ & $0(00.0)$ \\
\hline $\begin{array}{l}\text { Chlorocebus } \\
\text { tantalus }\end{array}$ & 1 & $1(100.0)$ & $1(100.0)$ & $1(100.0)$ & $0(00.0)$ & $0(00.0)$ & $0(00.0)$ \\
\hline $\begin{array}{l}\text { Erythrocebus } \\
\text { patas }\end{array}$ & 5 & $5(100.0)$ & $4(80.00)$ & $5(100.0)$ & $1(20.00)$ & $1(20.0)$ & $3(60.0)$ \\
\hline Papio Anubis & 8 & $8(100.0)$ & $6(75.0)$ & $5(62.5)$ & $0(00.0)$ & $3(37.5)$ & $0(00.0)$ \\
\hline Pantroglodytes & 3 & $3(100.0)$ & $2(66.7)$ & $3(100.0)$ & $0(00.0)$ & $1(33.3)$ & $1(33.3)$ \\
\hline Total & $\mathbf{1 8}$ & $\mathbf{1 8}(\mathbf{1 0 0 . 0})$ & $\mathbf{1 4}(\mathbf{7 7 . 8})$ & $\mathbf{1 5}(\mathbf{8 3 . 3})$ & $\mathbf{1 ( 5 . 6 )}$ & $\mathbf{6 ( 3 3 . 3 )}$ & $\mathbf{4 ( 2 2 . 4 )}$ \\
\hline
\end{tabular}

\section{Discussion}

A high number of isolates was recorded in this survey. Isolation of $E$. coli $(100 \%)$ at a constant rate throughout our study (especially if finally identified asbeing of human pathogenic serogroups) is an indicator of potential hazardous infections of sorrounding human communities. Enteropathogenic E. coli infection has been observed in approximately $20 \%$ of normal healthy neonatal and adult monkeys (rhesus macaques) (Mansfield $e t$ al., 2001; Sestak et al., 2003; Wachtman and Mansfield, 2008). Toxin producing Escherichia coli such as shiga toxigenic Escherechia coli (STEC) can cause a wide spectrum of ailments from mild diarrhoea to severe disease, in animals (Hall et al., 1985).

Prevalence of Salmonella paratyphi A showed mild increase by the end of or study, like wise Proteus mirabilis. Their increasing incidence during the period of study displays the continuing transmission amongst captive NHPs. Rates of occurrence of Campylobacter species, Citrobacter ferundii, Yersinia enterocolitica remained the same. It may imply that the mecahnisms which supported the thriving of $S$. paratyphi and $P$. mirabilis combined with their modes of spread were not condusive or supportive for these bacteria. Isolation of Salmonella species from NHPs and their further transmission to other primates has been reported by Mohan $e t$ al., (1973), Nizeyi et al., (2001) and Robert et al., (1969). They asserted that this could be due to its ability to survive in cool moist conditions for weeks outside the living body. Likewise they have been found in dried excreta for over 2.5 years. Its occurrence in these NHPs may thus indicate an enhanced anthropozoonotic transmission of these organisms.

We noted that the cage floors of these primates were quite unhygienic, the animals constantly littered them with faeces and urine, and these floors were not routinely cleaned and sanitized. In addition, the quadrupedal movement of these animals on the ground enhanced their contact with pathogens. These conditions 
no doubt provided pointers to some of the high prevalence values we recorded, being avenues for bacterial infection, re-infecton and dissemination of existing infections amongst previously unaffected animals.

Several reports have been presented on the isolation of Yersinia species from a variety of animals and human beings (Shepel et al., 2001., Skiriken, 2004., Okwori et al, 2008., 2009); descriptions of observed clinical manifestations or pathoanotomical changes are sparse (Hurvell, 1981; Schiemann, 1989).

Despite the successes in excluding select pathogens (Barry and Strelow, 2008; Morton and Capuono, 2008; Solnick et al, 1999) of NHP colonies, elimination of many other infectious diseases from NHP colonies has proven difficult for several reasons. The standard approach- based on cesearean derivation and isolation used to produce specific pathogen free population of many species of laboratory animals is difficult to reproduce in primates, given that parental input is critical in the normal social development of infants and juveniles. This approach may lead to future poor reproductive performance and behavioral issues (Harris et al, 2002; Suomi, 1997). Common primate housing and breeding strategies that are used to enhance socialization and welfare may promote transmission of many agents. The continued use of feral and free ranging source colonies introduces variability in exposure that is difficult to control. In addition, the long span and high value of many NHP species can restrict options available in the event of infection of animals.

The presence of these pathogenic bacteria has public health significance because of the proximity of these non-human primates to human dwellings (Mohan et al., 1973).

\section{Conclusion}

In this study we have identified bacteria present in NHP populations in Jos wild life park. We therefore caution that many of them may resurface in human habitations in close proximity to these animal dwellings. These organisms are transmitted majorly by the faecal-oral route which occurs mostly when animal wastes are not properly disposed. It is possible to control active bacterial infections by vigilant sampling of NHP populations and the appropriate use of antibiotics to eliminate shedding of bacteria and spread of the disease (Black-Schultz et al., 1997; Wolfensohn, 1998).

\section{References}

[1]. Barley C., Mansfield K.: Review paper: Emerging and reemerging infectious diseases of non-human primates in the laboratory setting. Veterinary pathology, May, 2010 vol 47(3): 462-481.

[2]. Barry PA, Strelow L: Development of breeding populations of rhesus macaques (Macaca mulatta) that are specific pathogen-free for rhesus cytomegalovirus. Comp Med 58:43-46, 2008.

[3]. Basu, S., Suri, J.C., Mohan, K. and Madan, M. (1975). Salmonella Indiana (1,4,12:Z: 1,7): a serotype isolated for the first time in India. Indian Journal of Medical Research. 63: 170 - 1 .

[4]. Bolton, F.J., Hutchison, D.N. and Parker, G. (1988). European Journal of Clinical Microbiological Infectious Diseases, 7, Pp. 155160.

[5]. Boro, B.R., Sarma, G. and Sarmah, A.K. (1980). Bacteriological investigation of enteric infections in zoo animals. Indian Journal of Animal Health. 19: 39 - 41 .

[6]. Bronsdon, M.A. and Schoenknecht, F.D. (1988). Campylobacter pylori isolated from the stomach of the monkey, Macaca nemestrina. Journal of Clinical Microbiology. 26(9): 1725-1728.

[7]. Black-Schltz, L., Coatney R.W., Warnick, C.L. and Swif, B. (1997). Lack of reactivation of shigellosis in naturally infected enrofloxacin-treated cynomolgus monkeys after exogenous immunosuppression. Lab Anim Sci 47: 602 - 605.

[8]. Engel, G.A., Hungerford, L., Jones-Engel, L., Travis, D., Fuentes, A. and Grant, R. (2006). Risk assessment: a model for predicting cross-species transmission of SFV from macaques (M. fascicularis) to humans at a monkey temple in Bali, Indonesia. Am. J. Primatol. In press.

[9]. Engel, G.A., Jones-Engel, L., Schillaci, M.A., Suaryana, K.G., Putra, A. and Fuentes, A. (2002). Human exposure to herpesvirus Bseropositive macaques, Bali, Indonesia. Emerg. Infect. Dis. 8: 78995.

[10]. FDA/CFSAN. (2001). Yersinia enterocolitica and Yersinia pseudotuberculosis. Bacteriological Analytical Manual. Online Chp. Pp.1-7. FDA - Centre For Food Safety and Applied Nutrition.

[11]. Fox, J.G., Handt, L., Xu, S., Shen, Z., Dewhirst, F.E., Paster, B.J., Dangler, C.A., Charles, A., Lodge, K., Motzel, S. and Klein, H. (2001). Novel Helicobacter species isolated from rhesus monkeys with chronic idiopathic colitis. Journal of Medical Microbiology. 50(5): 421-429.

[12]. Hall, G.A., Reynolds, D.J., Chanter, N., Morgan, J.H., Parsons, K.R., Debney, T.G., Bland, A.P. and Bridger, J.C. (1985). Dysentery caused by Escherichia coli (S102 - 9) in calves: natural and experimental disease. Veterinary Pathology. 22: 156 - 163.

[13]. Harris KA, Fidler KJ, Hartley JC, Vogt J, Klein NJ, Monsell F, Novelli VM: Unique case of Helicobacter sp osteomyelitis in an immunocompetent child diagnosed by broad-range 16S PCR. J Clin Microbiol 40:3100-3103, 2002.

[14]. Hurvell, B. (1981). Zoonotic Yersinia enterolitica infection: host range, clinical manifestations, and transmission between animals and man. In Botton, E.J. (Ed). Yersinia enterocolitica. CRC Press, Boca Raton, FL. Pp. 145 - 159.

[15]. Engel, G.A., Jones-Engel, L., Schillaci, M.A., Suaryana, K.G., Putra, A. and Fuentes, A. (2002). Human exposure to herpesvirus Bseropositive macaques, Bali, Indonesia. Emerg. Infect. Dis. 8: 78995.

[16]. Mansfield, K.G., Pauley, D., Young H.L. and Lackner, A.A. (1995). Mycobacterium avium complex in macaques with AIDS is associated with a specific strain of simian immunodeficiency virus and prolonged survival after primary infection. J. Infect. Dis. 172: $1149-1152$.

[17]. Mohan, K., Pal, S.C., Ghosh, J.N., Chakravarty, A.K., Pattanayak, S. and Arya, S.C. (1973). Enteric infections in captive monkeys. Indian Journal of Medical Research. 61: 363 - 8.

[18]. Morton WR, Agy MB, Capuano SV, Grant RF: Specific pathogen-free macaques: definition, history, and current production. ILAR J 49:137-144, 2008. 
[19]. Nizeyi, J.B., Innocent, R.B., Erume, J., Kalema, G.R., Cranfield, M.R. and Graczyk, T.K. (2001). Campylobacteriosis, Salmonellosis, and Shigellosis in free ranging human habituated mountain gorillas of Uganda. Journal of Wildlife Disease. $37: 239$ - 244.

[20]. Okwori, A.E.J., Agina, S.E., Olabode, O.A., Fadera, M.A.K., Ibu, J. and Odugbo, M. (2005). Faecal carriage of Yersinia species in pigs, sheep and poultry on display for sale in Vom and Bukuru areas of Jos South LGA, Plateau State, Nigeria. Nigerian journal of Microbiology.19(1-2): 444-451.

[21]. OKWORI A.E.J., C. OBIORA., S.E. AGINA., A.O. OLABODE., F.C. ONWULIRI (2008) Occurrence of Yersinia enterocolitica and Yersinia pseudotuberculosis in locally fermented cow milk (nono) in Bauchi metropolis, Nigeria. Nigerian Journal of Biotechnology Vol.19:5-11

[22]. OKWORI , A.E.J., PILAR O. M., MARIA FREDRIKSSON-AHOMAA.,S. E. AGINA., H. ORKEALA (2009) Pathogenic Yersinia enterocolitica 2/O:9 and Yersinia pseudotuberculosis 1/O:1 strains isolated from human and non-human sources in the Plateau State of Nigeria. Journal of food Microbiology (26): 872- 875.

[23]. Robert, C.G., Bessie, D.M. and Toshio, K. (1969). Enteric pathogens in monkeys. Journal of Bacteriology. 97: 1048-1055.

[24]. Schiemann, D.A. (1989). Yersinia enterocolotica and Yersinia pseudotuberculosis. In: Doyle, M.P. (Ed). Foodborne Bacterial Pathogens. Mercel Dekker, New York. Pp 601 - 672.

[25]. Sestak, K., Merritt, C.K., Borda J., Saylor, E., Schwamberger, S.R., Cogswell, F., Didier, E.S., Didier, P.J., Plauche, G., Bohm, R.P., Aye, P.P., Alexa, P., Ward, R.L. and Lackner, A.A. (2003). Infectious agent and immune response characteristics of chronic enterocolitis in captive rhesus macaques. Infec. Immun. 71: 4079 - 4086.

[26]. Shepel, M., Boyd, J., Luider, J. Gibb, A.P. (2001). Interaction of Yersinia enterocolitica and Yersinia pseudotuberculosis with pletelets. J. Med. Microbiol. 50 (12). 1030.

[27]. Srivastava, L., Mathew, T., Suri, J.C., Edward, E.J. and Sood, P.L. (1980). Carriage of Salmonella species by laboratory animals. Indian Journal of Pathological Microbiology. 23: $\quad 69-71$.

[28]. Skiriken, B. (2004). The presence of Yersinia enterocolitica and other Yersinia specie in ground beef in Aydin, Turkey. Turk. J. Vet. Animal Science. 28: 489 - 495.

[29]. Solnick JV, Canfield DR, Yang S, Parsonnet J: Rhesus monkey (Macaca mulatta) model of Helicobacter pylori: noninvasive detection and derivation of specific-pathogen-free monkeys. Lab Anim Sci 49:197-201, 1999.

[30]. Suomi SJ: Early determinants of behaviour: evidence from primate studies. Br Med Bull 53:170-184, 1997.

[31]. Wolfe, N.D., Switzer, W.M., Carr, J.K., Bhullar, V.B., Shanmugam, V. and Tamoufe, U. (2004). Naturally acquired simian retrovirus infections in central African hunters. Lancet. 363: 9327.

[32]. Wolfensohn, S. (1998). Shigella infection in macaque colonies: case report of an eradication and control program. Lab. Anim. Sci. 48: $330-333$. 